\title{
Interface Problems in Change Order-Challenged Projects
}

\author{
*Puti Marzuki, Adrianto Oktavianus, Almerinda Regina, Budi Hasiholan \\ and Meifrinaldi
}

Published online: 31 December 2019

To cite this article: Puti Marzuki, Adrianto Oktavianus, Almerinda Regina, Budi Hasiholan and Meifrinaldi (2019). Interface problems in change order-challenged projects. Journal of Construction in Developing Countries, 24(2): 1-22. https://doi. org/10.21315/jcdc2019.24.2.1.

To link to this article: https://doi.org/10.21315/jcdc2019.24.2.1

\begin{abstract}
Change orders are among the main sources of problems challenging timely completion of construction projects. The significantly needed conducive interaction among project participants to mitigate completion delay risk due to change orders is often hampered by interface problems. This article describes potential sources of interface problems and their role in affecting completion time of change order-challenged infrastructure construction projects in Indonesia. The identified sources then serve as inputs to formulate a systems thinking model of relational interface problems in change order-challenged projects. A survey of eleven important infrastructure construction projects was conducted to obtain data on the main sources of these interface problems and their severity indexes. A second survey was later conducted to perceive the most frequent causes of change orders, the influence of interface problem cause factors on the length of change order process and the influence of interface problem cause factors on the expediting capacity of a project team and ultimately induce a delay of project completion. The results of both surveys then served as inputs to a systems thinking structure showing the factors in a change order-challenged project. The study shows that contract, technical experience, management, coordination and financial aspects are the potential sources of interface problems in Indonesian infrastructure construction projects. In a change order-challenged project, these interface problems' sources will complicate the efforts to achieve the project's time objective. The study especially points out the role of contract documents' quality in increasing the likelihood and extent of change orders and the influence of workers' productivity in mitigating the negative impact of a change order.
\end{abstract}

Keywords: Interface problem, Delay, Construction project, Change order, Indonesia

\section{INTRODUCTION}

Organisational interactions among parties involved in a construction project are known to create relational interfaces. Relational or organisational interfaces are considered as links between these parties. Due to its multiple numbers of involved parties, participants or stakeholders, a construction project is said to be fragmented. Anumba, Kamara and Cutting-Decelle (2007) found that this fragmentation may lead to misperceptions and misunderstandings. Interface problems occur when a construction project's objective fulfilment depends on the interaction of two or more stakeholders in this fragmented environment.

Meanwhile, change, defined as any event that results in modification of the original scope, execution time or cost of work, is inevitable on most construction projects due to the uniqueness of each project and the limited available resources

Faculty of Civil and Environmental Engineering, Institut Teknologi Bandung, INDONESIA

*Corresponding author: puti@si.itb.ac.id 
of time and money. Change may occur on a project for a number of reasons, such as design errors, design changes, additions to the scope or unknown conditions (Hanna et al., 2002). A change order is work that is added to or deleted from the original scope of work of a contract, which alters the original amount of cost and/ or completion date. Change orders have long been identified to have a negative impact on construction productivity, causing a decrease in labour efficiency and, in some cases, considerable loss of man hours (Barrie and Paulson, 1996; Moselhi, 1998).

Satisfying project objectives despite change orders is one of the challenges faced in a construction project. In this regard, coordination among the stakeholders of a construction project is clearly very important. This means that interface problems in the project's organisation have to be well addressed so that their potential to cause a negative impact on the project is minimised.

This article is aimed to describe potential sources of interface problems and their role in affecting completion time of change order-challenged infrastructure construction projects in Indonesia. Based on identified sources, a systems thinking model of relational interface problems in the projects is formulated. This formulation is expected to help establish a good perception of potential problems and their mitigation efforts amidst Indonesia's need to accelerate its public infrastructure provision through an on time and on budget construction.

\section{LITERATURE REVIEW}

\section{Interfaces in a Construction Project as Sources of Problems}

Wren (1967) defines organisational interfaces as the points of contact between independent and interacting organisations working together to achieve common objectives. The achievement of a construction project's objectives requires bringing together independent multidisciplinary teams from multi-organisations working in a dynamic environment for a determinate amount of time. Through this act, several interfaces or interactions are temporarily created (Daniels, Farnsworth and Weidman, 2014). Besides organisational interfaces, Pavitt and Gibb (2003) mentioned that there are physical and contractual interfaces in a construction project. A lack of cooperation, limited trust and ineffective communication among the parties involved in a construction project will cause interface problems that could lead to delays, difficulty in resolving claims, cost overruns, litigations and compromise project quality (Moore, Mosley and Slagle, 1992).

Interface problems have been studied in several previous researches by, among others, Al-Hammad (2000), Huang et al. (2008) and Chen, Reichard and Beliveau (2008). Al-Hammad (2000) classifies interface problems into four general categories: financial, contract and specifications, environmental and other common interface problems. Meanwhile, Chen, Reichard and Beliveau (2008) identify comprehensive cause factors of interface problems from six interrelated perspectives: people/participants, methods, processes, resources, documentation, project management and environment. Marzuki, Oktavianus and Regina (2018) conducted a research on interface problems in Indonesian infrastructure construction projects mainly based on cause factors categorisation proposed by Al-Hammad (2000) and Chen, Reichard and Beliveau (2008). 
While interface problems and the related cause factors have been discussed by a number of researchers, the interconnectivity between them and the mechanism that hinder the achievement of a project's objective, mainly with regard to its timely completion, has not been shown. A system's thinking structure would be one of the most effective ways to describe this mechanism.

\section{Change Order Challenges in a Construction Project}

Hinze (1993) mentioned that whenever a change is ordered by the owner, it is usually referred to as a change order. The types and sources of change order according to Hinze (2001) cited in a study by Assbeihat and Sweis (2015) is shown in Table 1.

Table 1. Types and Sources of Change Orders

\begin{tabular}{ll}
\hline Type & Source \\
\hline Change in scope & Owner has requested to design change \\
Unforeseen conditions & $\begin{array}{l}\text { Site conditions differ from the expected: } \\
\text { Requested by contractor or professional }\end{array}$ \\
Professional errors and omissions & Requested by contractor or professional \\
Errors & $\begin{array}{l}\text { Professional has incorrectly drawn the construction } \\
\text { design plans and specifications }\end{array}$ \\
Omissions & $\begin{array}{l}\text { Professional has inadvertently omitted an item or } \\
\text { element from the plans }\end{array}$ \\
\hline
\end{tabular}

Source: Hinze (2001) as cited in Assbeihat and Sweis (2015)

Coping with the consequences of change orders in a construction project and the impact of these changes on project performance are still a subject of many studies. Moselhi, Assem and El-Rayes (2005) found that change orders continue to pose serious challenge to owners and contractors alike. Most of change orders issued during the construction period are major causes of time and cost overruns, disruption and disputes (Alnuaimi et al., 2010). Kaming et al. (1997) studied influencing factors on 31 high-rise building projects in Indonesia and found that design changes is one of the most important factors causing time overrun. Chan and Kumaraswamy (1997) carried out a comparative study of causes of time overruns in Hong Kong construction projects and compared the results with those found in Saudi Arabia and Nigeria. They found that client-initiated change orders are one of the major causes of time overrun.

Another challenge of change order in a construction project is its impact on project atmosphere. According to Alaryan et al. (2014) change orders strain the relationship of owners, engineer, contractors, subcontractors and others involved in the construction processes as well as add cost and schedule delay.

Change orders then have the potential to be the cause of and to aggravate interface problems in a construction project. On the other hand, good interfacing among project participants could mitigate the negative impacts of change orders on project performance. Previous researches have not studied in depth these potentials. A framework showing the interconnectivity between change 
orders, interface problems and their impact on a project's completion time would contribute to an overall assessment of the problem. A system's thinking structure will serve to understand the details and dynamics of causal relationships.

\section{METHODOLOGY}

A survey was first conducted to identify significant interface problems' potential cause factors in 11 Indonesian construction projects. These projects are chosen as samples because they are among the most important public infrastructure projects that have been pushed by the Indonesian government to be completed on time to fulfil needs of problem solving in the fields of transportation, housing, education and sports. The delivery methods of these projects, i.e. design-bid-build (three projects) and design-build (eight projects) represent the most adopted system in Indonesian infrastructure construction projects currently. Data were collected through a questionnaire distributed to respondents consisting of main project participants. The categorisation of interface problems' cause factors proposed by Al-Hammad (2000) and Chen, Reichard and Beliveau (2008) was adopted in setting up the questionnaire. The severity index of each potential cause factor was obtained based on the respondents' perception. Table 2 lists the projects and respondents involved in the questionnaire survey. A part of the survey's result (from five among the 11 projects) was already described in a previous article (Marzuki, Oktavianus and Regina, 2018). For the present article, the numbers of respondents are increased and the types of infrastructure constructed are more varied to obtain a more complete representation of Indonesian infrastructure construction projects.

Table 2. Projects and Respondents of Interface Problem Survey

\begin{tabular}{|c|c|c|}
\hline & Description & Respondents \\
\hline \multirow[t]{2}{*}{ Project 1} & Railway construction & Owner, designer, builder \\
\hline & D-B project delivery & \\
\hline \multirow[t]{2}{*}{ Project 2} & LRT construction & Owner, designer, builder \\
\hline & D-B project delivery & \\
\hline \multirow[t]{2}{*}{ Project 3} & Aquatic sport stadium construction & Owner, builder \\
\hline & D-B project delivery & \\
\hline \multirow[t]{2}{*}{ Project 4} & Athletic sport stadium construction & Owner, builder \\
\hline & D-B project delivery & \\
\hline \multirow[t]{2}{*}{ Project 5} & Apartment building construction & Owner, builder \\
\hline & D-B project delivery & \\
\hline \multirow[t]{2}{*}{ Project 6} & Educational building construction & Owner, designer, builder \\
\hline & D-B-B project delivery & \\
\hline \multirow[t]{2}{*}{ Project 7} & Toll road construction & Owner, designer, builder \\
\hline & D-B-B project delivery & \\
\hline
\end{tabular}

(continued on next page) 
Table 1. (continued)

\begin{tabular}{lll}
\hline & Description & Respondents \\
\hline Project 8 & $\begin{array}{l}\text { Apartment building construction } \\
\text { D-B-B project delivery }\end{array}$ & Designer, builder \\
Project 9 & Underpass 1 construction & Designer, builder \\
& D-B project delivery & \\
Project 10 & Underpass 2 construction & Designer, builder \\
& D-B project delivery & \\
Project 11 & Flyover construction & Owner, builder \\
& D-B project delivery & \\
\hline
\end{tabular}

Each respondent's perception with regard to the impact extent of each interface problem cause factor on project completion delay is also identified. Then, a severity index of each potential cause factor is calculated using the same formula applied by Al-Hammad (2000) as follows:

$$
\text { Severity Index }(I)=\frac{\left(\sum_{i=0}^{4}\left(a_{i}\right)\left(x_{i}\right)\right)}{\left(4 \sum\right)\left(x_{i}\right)} \times 100 \%
$$

where $a_{i}=$ constant expressing weight given to $i$ and $x_{i}=$ variable expressing frequency of $i$. These are applied as follows: $x_{0}=$ frequency of "very strongly affects" response and corresponds to $a_{0}=4, x_{1}=$ frequency of "strongly affects" response and corresponds to $a_{1}=3, x_{2}=$ frequency of "moderately affects" response and corresponds to $a_{2}=2, x_{3}=$ frequency of "strongly does not affect" response and corresponds to $a_{3}=1$ and $x_{4}=$ frequency of "very strongly does not affect" response and corresponds to $a_{4}=0$.

The severity index of $0 \%-12.5 \%$ is categorised as "Non-Severe", $12.5 \%-27.5 \%$ is categorised as "Somewhat Non-Severe", $37.5 \%-62.5 \%$ is categorised as "Moderately Severe", $62.5 \%-87.5 \%$ is categorised as "Severe" and $87.5 \%-100 \%$ is categorised as "Most Severe".

Factors with the highest severity indexes then serve as variables in the system thinking structure of interface problems in a change order-challenged infrastructure construction project set up later on.

A second survey was conducted to obtain respondents' perception on: (1) the most frequent causes of change orders, (2) the influence of interface problem cause factors on the length of change order process and (3) the influence of interface problem cause factors on the expediting capacity of a project team and ultimately induce a delay of project completion. The survey consisted of an interview and questionnaire-based data collecting that involved representatives of seven Indonesian infrastructure construction projects' team. Table 3 lists the projects and respondents involved in this second survey. 
Table 3. Projects and Respondents of Change Order Survey

\begin{tabular}{lll}
\hline & Description & Respondents \\
\hline Project 1 & Underpass 1 construction & CM consultant, contractor \\
Project 2 & Underpass 2 construction & CM consultant, contractor \\
Project 3 & Flyover construction & Owner \\
Project 4 & Apartment building construction & Owner \\
Project 5 & Toll road construction & Owner \\
Project 6 & Educational building construction & Owner \\
Project 7 & Apartment building construction & Contractor \\
\hline
\end{tabular}

A 0 to 4 scale is used to quantify respondents' answers where:

$0=$ "Not Frequent" or "Not Influential" $\left(a_{0}=0\right) ; x_{0}=$ frequency of "not frequent or not influential" response.

$1=$ "Less Frequent" or "Less Influential" $\left(a_{1}=1\right) ; x_{1}=$ frequency of "less frequent or less influential" response.

$2=$ "Moderately Frequent" or "Moderately Influential" $\left(a_{2}=2\right) ; x_{2}=$ frequency of "moderately frequent or moderately influential" response.

$3=$ "Frequent" or "Influential" $\left(a_{3}=3\right) ; x_{3}=$ frequency of "frequent or influential" response.

$4=$ "Very Frequent" or "Very Influential" $\left(a_{4}=4\right) ; x_{4}=$ frequency of "very frequent or very influential" response.

Respondents' perceptions are then processed and severity indexes are calculated similarly to the previously described calculation of an interface problem cause factor's severity index.

From the first and the second survey's results, an initial conceptual framework of interface problem cause factors categories involved in a change order process that induce project completion delay is drawn. The types and sources of change order according to Hinze (2001) are adopted as the starting point. This framework then serves as a basis to develop a systems thinking structure describing organisational interface problems cause factors' interconnectivity in a change order-challenged infrastructure construction project in Indonesia.

\section{RESULTS AND DISCUSSION}

\section{Organisational Interface Problem Cause Factors}

The 11 projects surveyed in this study are challenged by relatively complex problems and uncertainties inducing and aggravating interface problems. Table 4 shows interface problem factors found in the projects based on respondents' perception obtained through interviews. As in the previous study 
conducted by Marzuki, Oktavianus and Regina (2018), the factors are classified into six categories, namely contract, management, technical experience, coordination, financial and environment. The factors are a combination of those proposed previously by Al-Hammad (2000) and Chen, Reichard and Beliveau (2008). The main results that ought to be given special attention are as follows:

1. Respondents from Project 1 (double double-track railway construction project), Project 2 (LRT construction project), Project 6 (loan financed educational building construction project) and Project 11 (flyover construction project) identify more interface problem cause factors related to their projects compared to the other respondents. This is relevant to the extent of difficulties encountered in their respective projects.

2. Almost all of the respondents mentioned quality of contract documents and design interpretation capacity as potential interface problem cause factors to be addressed.

3. Work planning accuracy and activity schedule monitoring are the main management related interface problem cause factors that are perceived to exist in almost all of the projects.

4. Coordination capacity is perceived as part of the potential interface problem cause factors in almost all of the projects.

5. Risk management capacity is considered as one of the potential interface problem cause factor by most of the respondents.

6. Environmental factors, mainly complexity of organisation, complexity of permit processing and bureaucracy are notably identified in Project 6 (P6) which is a loan-financed educational buildings construction project.

Table 4. Potential Interface Problem Cause Factors

\section{No. Potential Cause Factors}

Project (P)

$\begin{array}{lllllllllll}1 & 2 & 3 & 4 & 5 & 6 & 7 & 8 & 9 & 10 & 11\end{array}$

1. Contract

(a) Quality of design/contract documents

(b) Quantity take off accuracy

(c) Change order processing

(d) Conflict resolution

(e) Procurement

2. Technical experience

(a) Skill and productivity of workers

(b) Construction method choice

(c) Safety management capacity

(d) Risk management capacity

(e) Design interpretation capacity

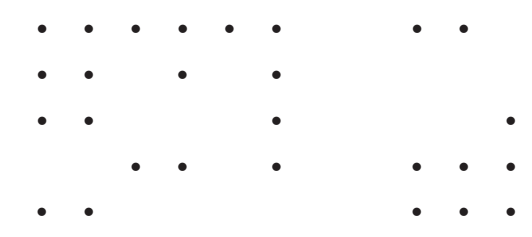


Table 4. (continued)

\section{No. Potential Cause Factors}

Project (P)

\section{$\begin{array}{lllllllllll}1 & 2 & 3 & 4 & 5 & 6 & 7 & 8 & 9 & 10 & 11\end{array}$}

3. Management

(a) Plant management

(b) Human resources management

(c) Activity schedule monitoring

(d) Work planning accuracy

(e) Work quality control

(f) Equipment and material quality control

(g) Supply chain management capacity

(h) Expediting capacity

(i) Cost performance monitoring capacity

(j) Information system management

(k) Project control capacity

4. Coordination
(a) Coordination capacity
(b) Communication skill
(c) Decision making capacity

5. Financial
(a) Owner's low budget
(b) Payment delay to contractors
(c) Inflation handling

6. Environment

(a) Complexity of organisation

(b) Complexity of regulation

(c) Length of approval process

(d) Policy implementation capacity

(e) Complexity of permit processing

(f) Communication with donor agency

(g) State budget disbursement complexity

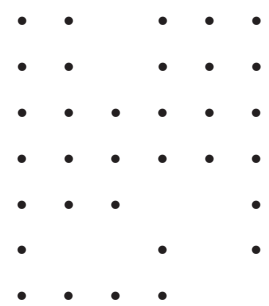

(h) Bureaucracy

(i) Weather

(j) Site condition

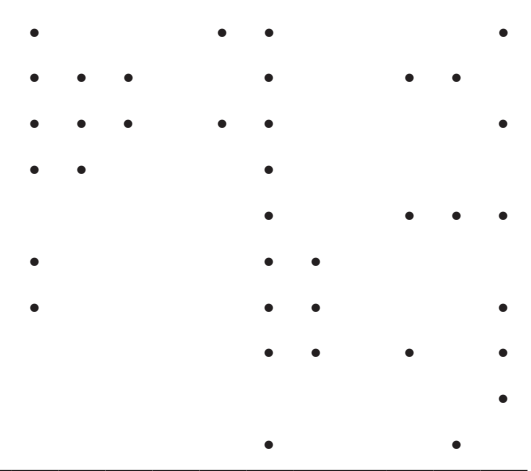

Notes: $\mathrm{P} 1$ = Railway construction; P2 = LRT construction; P3 = Aquatic stadium construction; P4 = Athletic sport stadium construction; P5 = Apartment building construction; P6 = Educational building construction; $\mathrm{P} 7$ = Toll road construction; $\mathrm{P} 8$ = Apartment building construction; $\mathrm{P} 9$ = Underpass 1 construction; $\mathrm{P} 10=$ Underpass 2 construction; $\mathrm{P} 11$ = Flyover construction. 
Meanwhile, Table 5 shows the highest severity indexes of the identified interface problem cause-factors. These factors later on serve as elements or variables of a systems thinking structure describing a change order-challenged construction project.

Table 5. Highest Severity Indexes of Identified Interface Problem Cause Factors

\begin{tabular}{|c|c|c|}
\hline \multicolumn{3}{|l|}{ Based on Builder's Perception } \\
\hline Potential Cause Factors & Severity Index (\%) & Rank \\
\hline Work planning accuracy & 64.77 & 1 \\
\hline Activity schedule monitoring & 59.09 & 2 \\
\hline Risk management capacity & 55.68 & 3 \\
\hline Construction method choice & 50.00 & 4 \\
\hline Design interpretation capacity & 46.59 & 5 \\
\hline Supply chain management capacity & 40.91 & 6 \\
\hline \multicolumn{3}{|l|}{ Based on Designer's Perception } \\
\hline Potential Cause Factors & Severity Index (\%) & Rank \\
\hline Work planning accuracy & 60.23 & 1 \\
\hline Activity schedule monitoring & 60.23 & 2 \\
\hline Risk management capacity & 57.95 & 3 \\
\hline Conflict resolution & 51.14 & 4 \\
\hline Construction method choice & 45.45 & 5 \\
\hline Design interpretation capacity & 45.45 & 6 \\
\hline \multicolumn{3}{|l|}{ Based on Owner's Perception } \\
\hline Potential Cause Factors & Severity Index (\%) & Rank \\
\hline Quality of design drawings/contract documents & 49.00 & 1 \\
\hline Construction method choice & 49.00 & 2 \\
\hline Design interpretation capacity & 45.00 & 3 \\
\hline Length of approval process & 41.00 & 4 \\
\hline Policy implementation capacity & 33.00 & 5 \\
\hline Complexity of permit processing & 30.00 & 6 \\
\hline
\end{tabular}

Influence of Interface Problem Cause Factors on Project's Time Performance in a Change Order Situation

Change order situations were experienced in most of the projects surveyed in this study. Difficulties related to complex project sites and engineering designs, new requests from the government in public infrastructure projects and some constructability issues are among the current causes of change order decisions that in turn become potential sources of interface problems' factors. 
The perception of respondents on the influence severity of each factor's frequency and impact with regard to change order-challenged infrastructure construction projects' time performance is shown on Table 6.

Table 6. Cause Factors and Change Order: Respondents' Perception

\begin{tabular}{|c|c|c|}
\hline \multicolumn{3}{|l|}{ Most Frequent Causes of Change Orders } \\
\hline Cause Factors & Severity Index & Rank \\
\hline Site condition differs from the expected & 69.44 & 1 \\
\hline Omission of elements from the plans & 38.89 & 2 \\
\hline Owner requested design/specification change & 36.11 & 3 \\
\hline Errors of design and specifications & 36.11 & 4 \\
\hline \multicolumn{3}{|c|}{ Influence of Interface Problem Cause Factors on the Length of Change Order Process } \\
\hline Cause Factors & Severity Index & Rank \\
\hline Expediting capacity & 63.89 & 1 \\
\hline Quantity take off accuracy/quality of contract documents & 61.11 & 2 \\
\hline Risk management capacity & 44.44 & 3 \\
\hline Productivity of workers & 41.67 & 4 \\
\hline \multicolumn{3}{|c|}{$\begin{array}{l}\text { Influence of Interface Problem Cause Factors on Change Order Process Expediting } \\
\text { Capacity of a Project Team }\end{array}$} \\
\hline Cause Factors & Severity Index & Rank \\
\hline Administrative skill & 75.00 & 1 \\
\hline Communication skill & 69.44 & 2 \\
\hline Complexity of project organisation & 61.11 & 3 \\
\hline Decision making capacity & 61.11 & 4 \\
\hline
\end{tabular}

Respondents perceive "site condition differs from the expected" as the most frequent cause of change orders. This is, in Indonesian public infrastructure projects, mostly related to the quality of design drawings, as part of contract documents, which are often lacking in thorough site survey as design basis. With regard to the length of change order process, "expediting capacity" of a project's team is considered to be the most influential factor. Meanwhile, this "expediting capacity" is significantly influenced by administrative and communication skill. The needs for these skills are naturally higher in a more complex project organisation. Meanwhile, "decision making capacity" is understandably very important to accelerate all change order processes.

\section{Initial Conceptual Framework of Systems Thinking Structure Development}

Figure 1 depicts an initial conceptual framework of interface problem potential cause factors categories in a change order-challenged construction project. Owner requested design change, site condition differs from the expected, errors of design and specifications and omissions elements form the plans, as observed by 
Hinze (2001), are shown as sources of change order. Among the main challenges in this situation is addressing interface problems that could induce project completion delay. Interface problems caused by a lack of project management capacity, technical experience, clarity of contract documents, financial capacity, expediting capacity and environmental problems would complicate the effort to minimise the length of change order process, and ultimately, will very likely have an impact on timely project completion. Hanna et al. (2002) defines the processing time as the time between the initiation of the change order and the owner's approval of the change order.

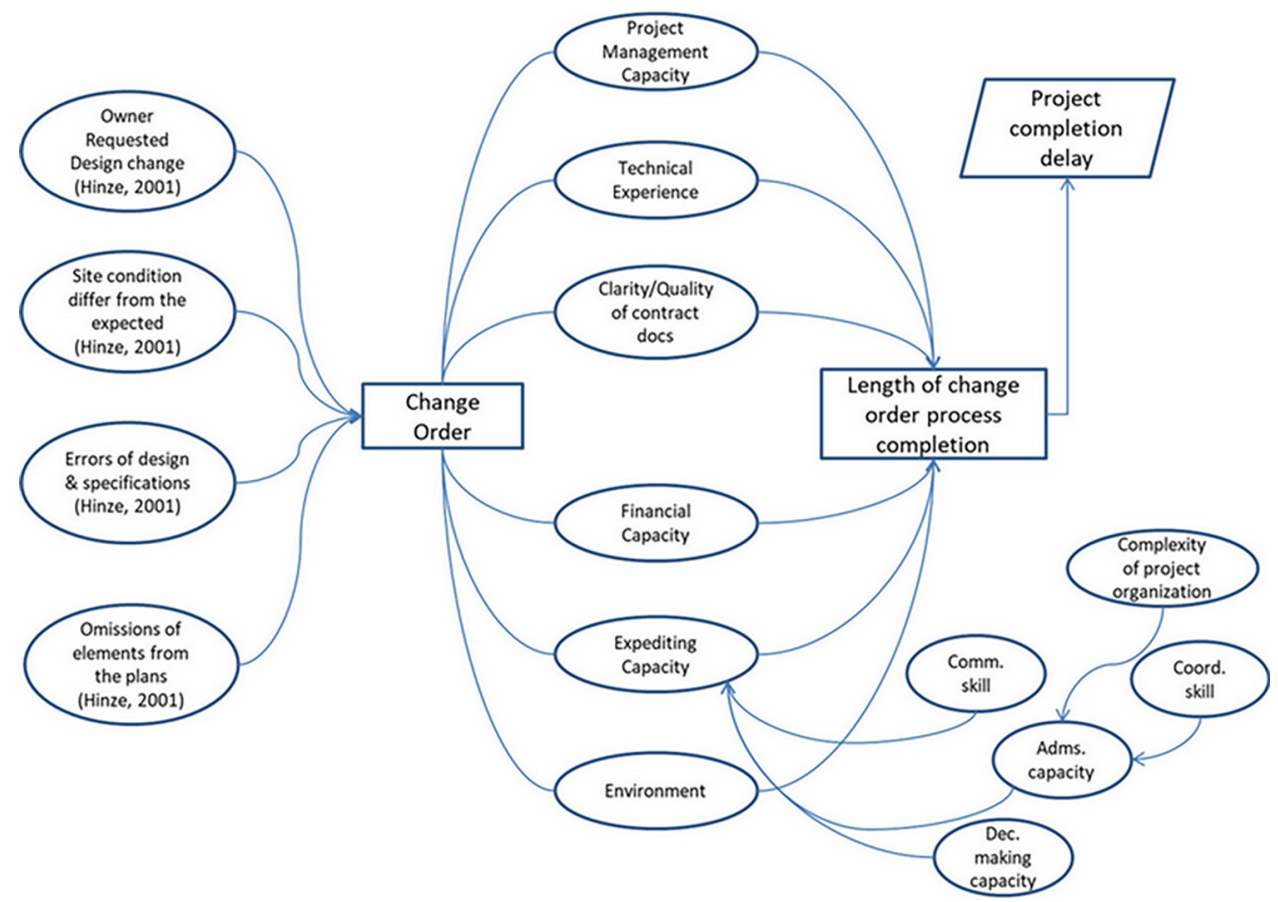

Figure 1. Initial Conceptual Framework of Interface Problem's Cause Factors Categories in a Change Order-Challenged Construction Project

Based on Figure 1, the followings are some considerations on interface problem cause factors categories with regard to project completion delay in a change order situation.

\section{Project management capacity}

Dainty, Cheng and Moore (2003) cited Cooke-Davis (2001) who declares that project management competence is one of many criteria upon which project performance is contingent. Wang (2000) argued that conflicts between the parties were more frequent in projects marked by poor management. Good project management involves effective planning and scheduling which are very influential in minimising project delay through effective anticipation. This significance is also 
brought up by Das and Ngacho (2017). In fact, as mentioned by Kavanagh, Muller and O'Brien (1978), the most useful and significant control mechanism in construction is the previously prepared time schedule. On the other hand, in this regard, Johnston and Brennan (1996) proposed management-as-organising instead of management-by-planning. It is suggested to see management as organising things rather than planning or scheduling them. This view might be more suitable for an environment where activities are repetitive. In complex and unique infrastructure construction projects, where very few activities are repetitive in nature and where all of them have to be executed according to conditions of contract, planning and scheduling including project control would still be very important parts of project management capacity required to achieve project objectives. On the contractors' side, project management capacity corresponds to their overall ability to manage and administer their prime contract with the owner (Mosley and Bubshait, 2016).

\section{Clarity of contract documents}

In construction, a delay means a time overrun either beyond the contract date or beyond the date that the parties have agreed upon for the delivery of the project. In both cases, a delay is usually a costly situation (O'Brien, 1976). In this regard, clarity or quality of contract documents would play a very significant role in achieving the time objective of the project especially when there is a change order to be processed. Good quality contract documents are especially important in a construction project where many participants are involved and interfaces are created among them. Interface problems are expected to be minimised when contract documents has high clarity which would avoid perception discrepancies among involved parties. Regarding contract documents' clarity, Assaf, Al-Hammad and Al-Shihah (1996) and Fisk (1997) remarked that in a multiplayer environment like construction, the plans and specifications must be clear and unambiguous for better understanding of the required job. Inadequate plans or working drawings and specifications can cause major variations that may eventually affect project completion. This is because a change in the plans and specifications during the construction phase requires changes in the construction planning, costing and procurement activities. If the specifications or plans are incomplete or unclear, it will create interpretation problems which will affect the quality of the project. This creates inconsistencies at the design and construction interface (Al-Hazmi, 1987). Conflicts are more probable in an environment challenged by change order situation where project participants are obliged to work harder to complete the process and thus their mutual perception on project objectives are essential. Incomplete plans and specifications are among the main causes of confusions among project participants that may prolong the change order process.

\section{Technical experience}

A sufficient amount of technical experience on the contractor's side is essential to execute what is expected in the contract and thus minimise interface problems with the other project participants especially in a change order situation. A good technical experience of contractors would enhance their capacity of design interpretation. This is important because, as mentioned by Kostoff (1977) and Chappell and Willis (1996), drawing details and specifications are the only means 
for the contractor to comprehend the job requirements and thereby chose an appropriate construction method.

Technical experience would allow contractors to well manage construction site. Poor site management, as revealed by Pickavance (2000), causes project delay and affects productivity. Problems would be more effectively solved when workers have good skill and productivity.

\section{Financial capacity}

Al-Hammad (2000) classifies common cause factors of interface problems associated with financial abilities of the construction parties to complete the projects based on their estimations and process of payment. These problems include delay in progress payment by owner, accuracy of the project cost estimate, owner's low budget for construction relative to requirements and price changes of materials and labourers during construction. In a change order situation, financial capacity-caused interface problems, especially payment delays will certainly affect the length of the process by disturbing material and other resources' delivery, which, in turn, impact labour productivity. Late payments will also induce adversarial atmosphere among project participants. In fact, Chan and Suen (2005) and Kennedy (2006) are of the opinion that irregular payments are a major cause of disputes.

\section{Expediting capacity}

It is the contractor's responsibility to ensure that equipment and material are delivered to the job site in proper sequence. This includes the contractual responsibility to expedite the delivery of material and equipment from his suppliers and various manufacturers (Kavanagh, Muller and O'Brien, 1978). Expediting capacity requires a good supply chain management on the contractor's side. Contractors' expediting capacity will certainly be influenced by punctual payments from the owner. In a change order situation, lack of contractors expediting capacity will impact process completion time. Besides related to the delivery of material and equipment, expediting capacity can also include the capacity to accelerate the whole change order completion process. As depicted in Figure 1, this capacity depends on communication skill, administrative capacity and decision making capacity of the main project participants. Meanwhile, administrative capacity will also be influenced by the coordination skill of project participants and project's complexity.

Coordination is important in a multi-participant environment as in most construction projects (Al-Hazmi, 1987; Clough and Sears, 1994). A lack of coordination between parties may cause conflicts that could eventually impact the project adversely. Errors which occurred can usually be resolved early with due diligence in coordination.

\section{Environment}

Potential interface problem cause factors in a construction project include aspects related to its environment. Complexity of the whole project's organisation and complexity of prevailing regulations are among the most influential factors challenging the achievement of time objective of a construction project as these 
factors relate to bureaucracy and degree of difficulties of obtaining approvals on matters of importance such as government budget disbursement or concurrence with donor institutions in public infrastructure construction projects. Meanwhile, other environmental factors such as weather and site condition or physical environmental condition, according to Faridi and Sayegh (2006), are factors over which no party to a contract has control but have to be addressed as risks to mitigate.

\section{Systems Thinking Structure}

Based on the identification of potential interface cause factors with the highest severity indexes (as shown in Table 5) and the initial conceptual framework regarding a change order-challenged infrastructure construction project (as shown in Figure 1), a systems thinking structure is created as depicted on Figure 2.

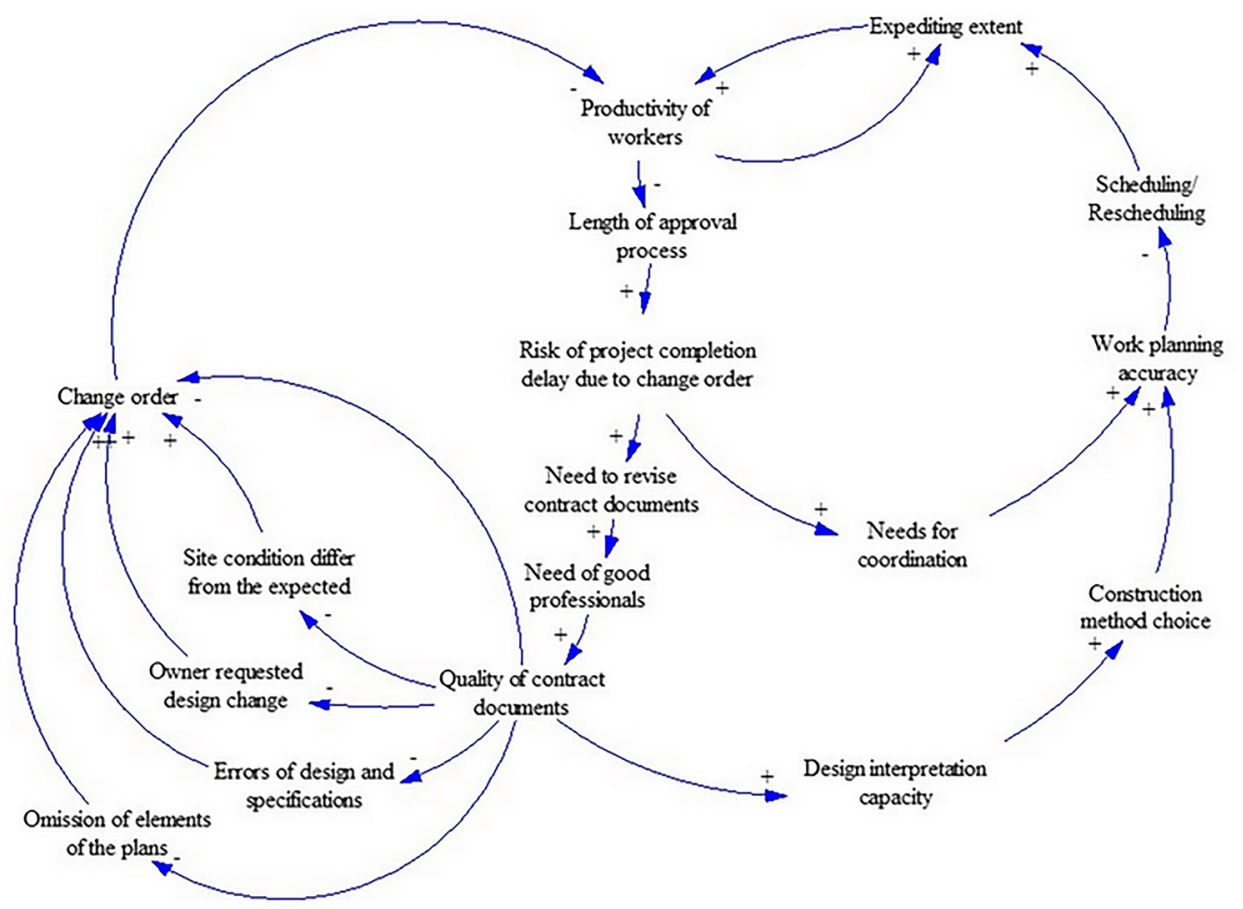

Figure 2. Systems Thinking Structure of Interface Problems' Cause Factors in a Change Order-Challenged Construction Project

The systems thinking structure is expected to contribute to the understanding of the complex interconnectivity of interface problem cause factors during a change order situation that could end up in the delay of project completion. The systems thinking structure can be used later in the continuation of this research to study the dynamic behaviour of the relationships.

Quality of contract documents and productivity of workers are seen as the main interface problem cause-factors with significant role in determining the 
impact of a change order situation on project completion time. A mediocre quality of contract documents would increase the likelihood and extent of change orders in a construction project. Meanwhile, productivity of workers will act as a balancing element to the negative impact of a change order by reducing the length of approval process or the whole change order completion process.

\section{Feedback loops}

Sterman (1992) observes that construction projects are inherently complex and dynamic, involving multiple feedback processes. With regard to the current study, the feedback processes contains interrelated interface problem cause factors that will drive the complexity of a construction project during a change order situation and will consequently increase the risk of project completion delay.

\section{Reinforcing Loop 1}

The reinforcing loop on Figure 3 is a part of the systems thinking structure showing the importance of contract documents' quality and productivity of workers in minimising the risk of project completion delay due to change order. A good quality contract will lower the likelihood of confusions among project participants and also reduce the extent of change orders in a construction project.

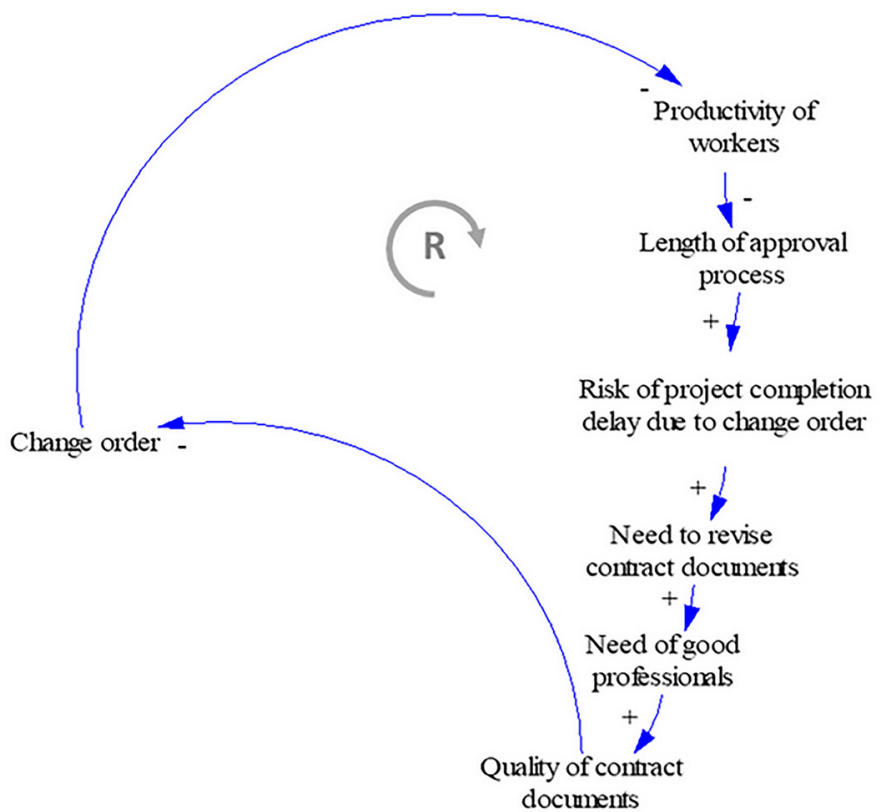

Figure 3. Reinforcing Loop 1

A change order will have a negative impact on the productivity of workers as revealed by a research conducted by Moselhi, Assem and El-Rayes (2005). On the other hand if a contractor succeeds in maintaining a high productivity of workers 
during a change order situation, the length of the corresponding completion and approval of processes can be expected to be shorter. Consequently, the risk of project completion delay will also be lower. The higher the risk of delay, the more revisions of the contract documents will likely be needed. Contract revisions will need the involvement of good professionals to come up with solid documents that, in turn, will again minimise change orders.

\section{Balancing Loop 1}

The length of approval process with regard to activities that are required to be executed due to a change order, will affect the risk of project completion delay. Therefore, a good coordination among project participants is needed to mitigate this risk. This good coordination will enable the contractor to plan the works to be conducted more accurately and consequently any scheduling or rescheduling can also be better anticipated. Activity scheduling and rescheduling needed in connection with a change order will determine the extent of expediting effort needed to maintain the expected time of project completion under control. Efforts needed to expedite related activities include maintaining a good productivity of workers which, in turn, can be expected to minimise the length of process completion and approvals during a change order situation. The balancing Loop 1 depicts this situation (as shown in Figure 4).

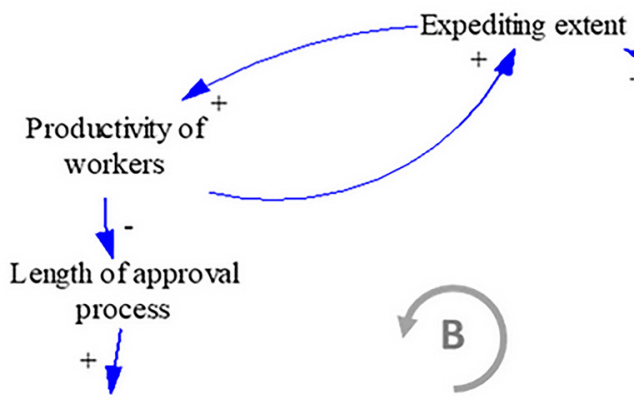

Risk of project completion delay due to change order

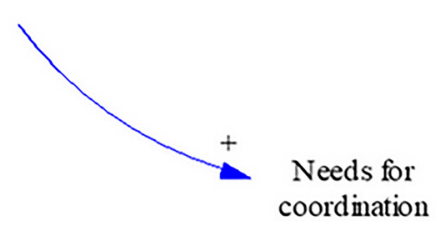

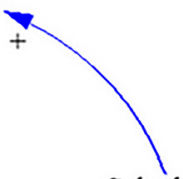

Scheduling/ Rescheduling

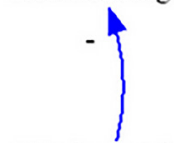

Work planning

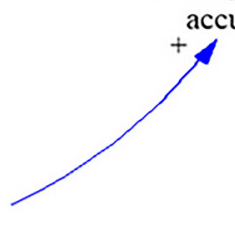

Figure 4. Balancing Loop 1 


\section{Balancing Loop 2}

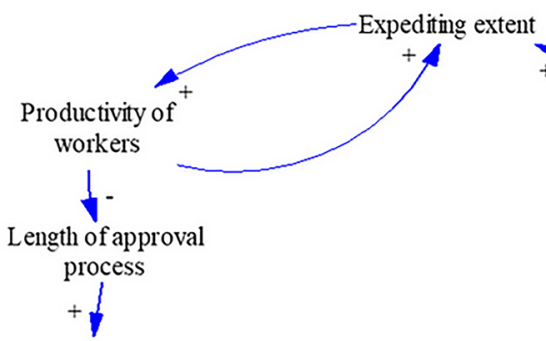

Risk of project completion delay due to change order

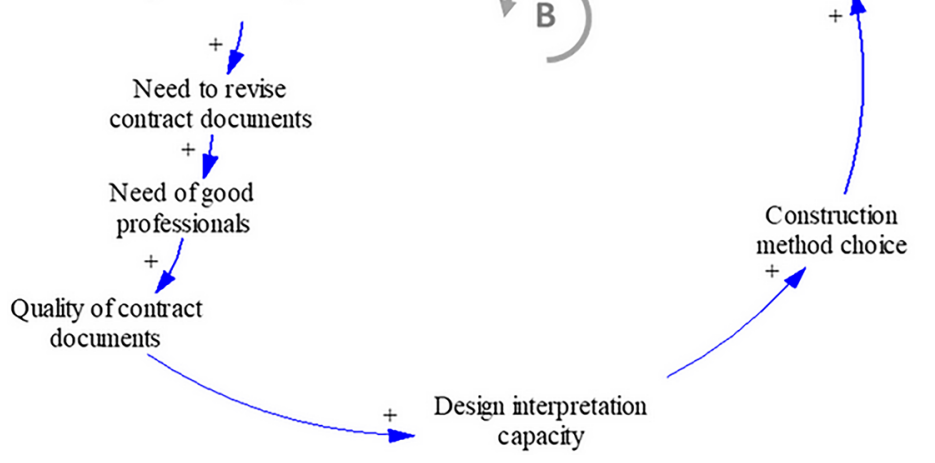

Figure 5. Balancing Loop 2

As described in balancing Loop 1, the length of process completion and approval with regard to activities that are required to be executed in connection with a change order, will affect the risk of project completion delay. The higher the risk of delay, the more revisions of the contract documents will likely be needed. Contract revisions will need the involvement of good professionals to come up with solid contract documents. Good quality contract documents will enhance the design interpretation capacity of involved parties. For contractors, a good interpretation of design documents will allow them to choose a most appropriate construction method which, in turn, will facilitate their work plan and scheduling or rescheduling. A good work schedule will help to anticipate the extent of expediting needed which is important to boost worker's productivity. With a good productivity of workers, acceleration of work completion will be facilitated and consequently the length of approval process needed in a change order situation can be expected to be shorter.

\section{Reinforcing Loop 2}

In reinforcing Loop 2 (as shown in Figure 6), the important role of contract documents' quality is again shown. Good quality contract documents will help to avoid the occurrence of changes caused by either differing site condition from the expected, errors of design and specifications or omission of elements of the plans which are the main sources of change orders. 


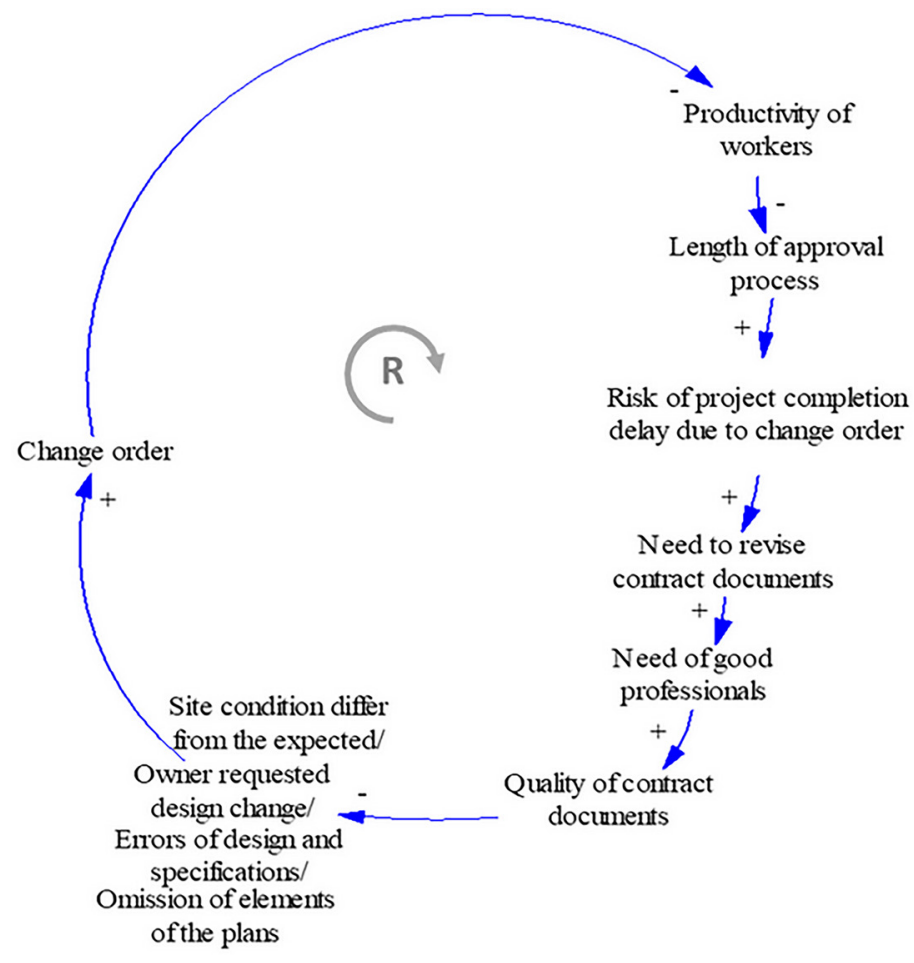

Figure 6. Reinforcing Loop 2

With less change orders, the productivity of workers can be expected to remain high, various works can be completed in a shorter time and thus any needed approvals are more likely to be obtained without much delay. The more approval processes are delayed the higher the risk of project completion delay and the need to revise contract documents. Good professionals are needed for this revisions and to ultimately produce good quality contract documents.

\section{Systems thinking structure's complete loops}

The complete balancing and reinforcing loops is shown on Figure 7. 


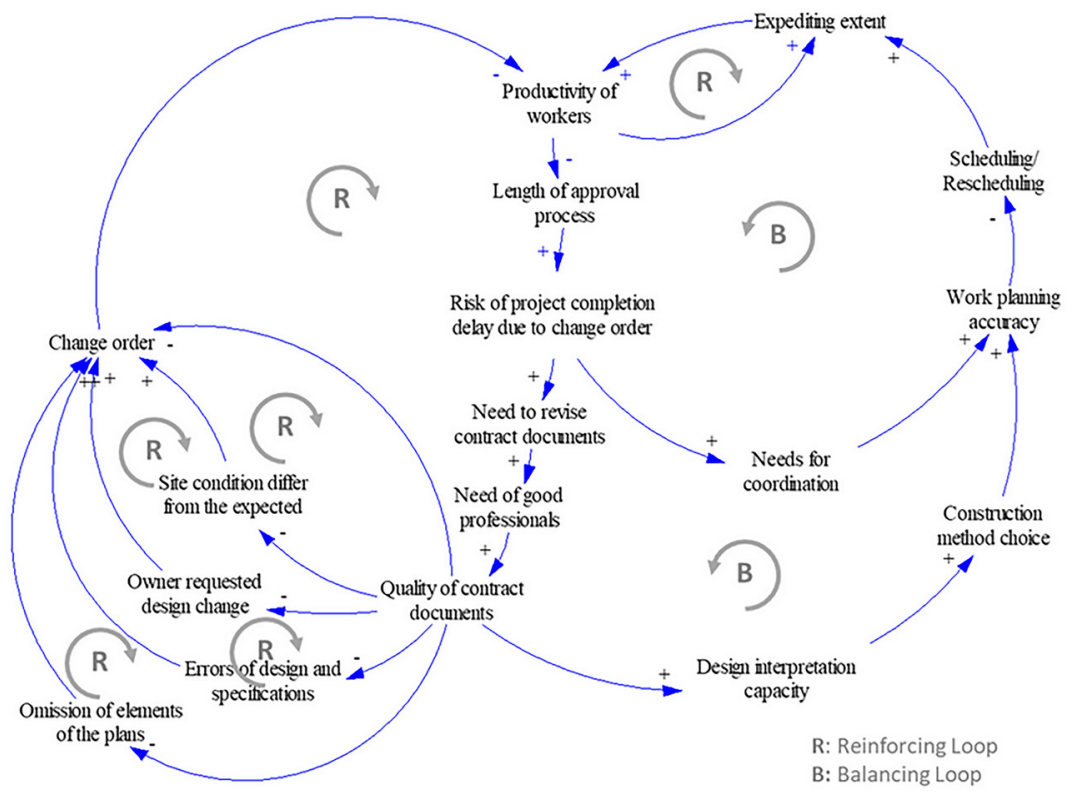

Figure 7. Complete Feedback Loops

\section{CONCLUSION}

Interface problems apparently affect many Indonesian infrastructure construction projects. Interface problems cause factors including quality of contract documents, design interpretation capacity, work planning accuracy, scheduling, supply chain management and risk management capacity have the most important influence on a project's completion time. In a change order-challenged infrastructure construction project, these potential sources of interface problems will complicate the efforts to achieve the time objective of a project. The perception of respondents indicates that "differing site condition from the expected" is the most frequent cause of change orders. In Indonesian construction projects, this is mostly related to the quality of design drawings and specifications, as part of contract documents, which are often lacking in thorough site surveys as design basis. On the other hand, the negative impact of change orders can be expected to be minimised when a contractor succeeds in maintaining the productivity of its workers. Then, in change order-challenged infrastructure construction projects, quality of contract documents and productivity of workers are the main potential sources of interface problems to be addressed to mitigate the risk of project completion delay.

The findings of this research represent the specific situation of Indonesian public infrastructure construction projects where project management quality and capacity are still to be enhanced which in certain aspects might differ from what is found in other countries. The conceptual framework showing an overall interconnectivity between the sources of change order, potential interface problems' cause factors and completion time of construction projects described in this article would help the parties involved, especially owners, to have a 
better understanding of the whole system to promote a conducive environment supporting the achievement of projects' objectives. Meanwhile, the infrastructure sector could benefit of the proposed system thinking structure to focus on the most important factors that play the key role to mitigate change order, improve productivity and reduce project delay. The research is planned to be continued with system dynamics' simulations based on the set up system thinking structure to enrich inputs for a more effective improvement of infrastructure construction project management in Indonesia.

\section{REFERENCES}

Al-Hammad, A.-M. (2000). Common interface problems among various construction parties. Journal of Performance of Constructed Facilities, 14(2): 71-74. https:// doi.org/10.1061/(asce)0887-3828(2000) 14:2(71).

Alaryan, A., Emadelbeltagi, El-Shahat, A. and Dawood, M. (2014). Causes and effects of change orders on construction projects in Kuwait. Journal of Engineering Research and Applications, 4(7): 1-8.

Al-Hazmi, M.H.S. (1987). Causes of delays in large building construction projects. MSc diss. King Fahd University of Petroleum and Minerals.

Alnuaimi, A., Taha, R., Mohsin, M. and Al-Harthi, A. (2010). Causes, effects, benefits and remedies of change orders on public construction projects in Oman. Journal of Construction Engineering and Management, 136(5): 615-622. https://doi.org/10.1061/(asce)co.1943-7862.0000154.

Anumba, C., Kamara, J. and Cutting-Decelle, A.-F., eds. (2007). Concurrent Engineering in Construction Projects. London and New York: Spon Research.

Assaf, S.A., Al-Hammad, A.M. and Al-Shihah, M. (1996). Effects of faulty design and construction on building maintenance. Journal of Performance of Constructed Facilities, 10(4): 171-174.

Assbeihat, J.M. and Sweis, G.J. (2015). Factors affecting change orders in public construction projects. International Journal of Applied Science and Technology, 5(6): 36-63.

Barrie, D. and Paulson, B. (1996). Professional Construction Management. 3rd Ed. New York: McGraw-Hill, Inc.

Chan, D.W.M. and Kumaraswamy, M.M. (1997). A comparative study of causes of time overruns in Hong Kong construction projects. International Journal of Project Management, 15(1): 55-63. https://doi.org/10.1016/s02637863(96)00039-7.

Chan, E.H.W. and Suen, H.C.H. (2005). Dispute resolution management for construction projects in China. Management Decision, 43(4): 589-602. https:// doi.org/10.1 108/00251740510593576.

Chappell, D. and Willis, A. (1996). The Architect in Practice. 8th Ed. Oxford: Blackwell Science Ltd.

Chen, Q., Reichard, G. and Beliveau, Y. (2008). Multiperspective approach to exploring comprehensive cause factors for interface issues. Journal of Construction Engineering and Management, 134(6): 432-441. https://doi. org/10.1061/(asce)0733-9364(2008)134:6(432).

Clough, R.H. and Sears, G.A. (1994). Construction Contracting. 6th Ed. Hoboken, NJ: John Wiley \& Sons, Inc. 
Cooke-Davis, T. (2001). The "real" success factors on projects. International Journal of Project Management, 20(3): 185-190. https://doi.org/10.1016/S02637863(01)00067-9.

Dainty, A.R.J., Cheng, M. and Moore, D.R. (2003). Redefining performance measures for construction project managers: An empirical evaluation. Journal of Construction Management and Economics, 21 (2): 209-218. https://doi.org/1 $0.1080 / 0144619032000049737$.

Daniels, C., Farnsworth, C.B. and Weidman, J. (2014). Interface management in mega projects. 50th ASC Annual International Conference Proceedings. Fort Collins, CO: Associated Schools of Construction.

Das, D. and Ngacho, C. (2017). Critical success factors influencing the performance of development projects: An empirical study of Constituency Development Fund in Kenya. IIMB Management Review, 29(4): 276-293. https://doi. org/10.1016/j.iimb.2017.11.005.

Faridi, A.S. and El-Sayegh, S.M. (2006). Significant factors causing delay in the UAE construction industry. Journal of Construction Management and Economics, 24(11): 1167-1176. https://doi.org/10.1080/01446190600827033.

Fisk, E.R. (1997). Construction Project Administration. 5th Ed. Prentice-Hall.

Hanna, A., Camlic, R., Peterson, P.A. and Nordheim, E.V. (2002). Quantitative definition of projects impacted by change orders. Journal of Construction Engineering and Management, 128(1): 57-64. https://doi.org/10.1061/ (ASCE)0733-9364(2002) 128:1 (57).

Hinze, J. (2001). Construction Contracts. 2nd Ed. New York: McGraw-Hill, Inc.

Hinze, J. (1993). Construction Contracts. New York: McGraw-Hill, Inc.

Huang, R.-Y., Huang, C.-T., Lin, H. and Ku, W.-H. (2008). Factor analysis of interface problems among construction parties: A case study of MRT. Journal of Marine Science and Technology, 16(1): 52-63.

Johnston, R.B. and Brennan, M. (1996). Planning or organizing: The implications of theories of activity for management of operations. Omega, International Journal of ManagementScience, 24(4):367-384. https://doi.org/10.1016/03050483(96)00016-3.

Kaming, P., Olomlaiye, P., Holt, G. and Harris, F. (1997). Factors influencing construction time and cost overruns on high-rise projects in Indonesia. Construction Management and Economics, 15(1): 83-94. https://doi. org/10.1080/014461997373132.

Kavanagh, T.C., Muller, F. and O'Brien, J.J. (1978). Construction Management. New York: McGraw-Hill, Inc.

Kennedy, P. (2006). Progress of statutory adjudication as a means of resolving disputes in construction in the United Kingdom. Journal of Professional Issues in Engineering Education and Practice, 132(3): 236-247. https://doi.org/10.1061/ (ASCE) 1052-3928(2006) 132:3(236).

Kostoff, S. (1977). The Architect: Chapters in the History of the Profession. Oxford: Oxford University Press.

Marzuki, P.F., Oktavianus, A. and Regina, A. (2018). Interface problems in construction projects. Paper presented at the 20th International Conference on Construction Engineering and Project Management. Paris, France, 25-26 June.

Moore, C., Mosley, D. and Slagle, M. (1992). Partnering guidelines for win-win project management. Project Management Journal, 22(1): 18-21. 
Moselhi, O. (1998). Estimating the cost of change orders. Transactions of the American Association of Cost Engineers, EST.06.1-EST.06.5.

Moselhi, O., Assem, I. and El-Rayes, K. (2005). Change orders impact on labor productivity. Journal of Construction Engineering and Management, 131 (3): 354-359.

Mosley, J.C. and Bubshait, A.A. (2016). Performance evaluation of international contractors in Saudi Arabia. Journal of Professional Issues in Engineering Education and Practice, 142(1): 04015007. https://doi.org/10.1061/(ASCE) El.1943-5541.0000254.

O'Brien, J.J. (1976). Construction Delay: Responsibilities, Risk and Litigation. Boston: Cahners Books International, Inc.

Pavitt, T.C. and Gibb, A.G.F. (2003). Interface management within construction: In particular, building façade. Journal of Construction Engineering and Management, 129(1): 8-15. https://doi.org/10.1061/(ASCE)07339364(2003) 129:1 (8).

Pickavance, K. (2000). Delay and Disruption in Construction Contracts. 2nd Ed. London: LLP Professional Publishing.

Sterman, J.D. (1992). System Dynamics Modeling for Project Management. Cambridge, MA: MIT Sloan School of Management.

Wang, Y. (2000). Coordination issues in Chinese large building projects. Journal of Management in Engineering, 16(6): 54-61. https://doi.org/10.1061/ (ASCE)0742-597X(2000) 16:6(54).

Wren, D.A. (1967). Interface and inter-organizational coordination. The Academy of Management Journal, 10(1): 69-81. 